\title{
Improved Design and Recommendations for Street Lighting in Gitega City
}

\author{
Ntawuhorakomeye Noel $^{1, *}$, Ndayiragije Leonidas ${ }^{2}$, Belov Mikhail Petrovich $^{1}$ \\ ${ }^{1}$ Department of Robotics and Industrial Automation, Saint- Petersburg Electrotechnical University ETU"LETI", 197227, Russia \\ ${ }^{2}$ Department of Electromechanical Engineering, Burundi University, 1550, Burundi
}

\begin{abstract}
A R T I C LE INFO
Article history:

Received: 07 September, 2020

Accepted: 01 December, 2020

Online: 16 December, 2020
\end{abstract}

\section{Keywords:}

Solar mini power plant

Gitega climate

Public lighting

Smart lamp

\begin{abstract}
A B S T R A C T
The article discusses the possibility of using solar energy for street lighting systems in the city of Gitega, in the Republic of Burundi. Analysis of weather and climate conditions of the city was carried out and an effective street lighting system based on solar mini-power plants using an intelligent control system developed. Calculations of technical and economic efficiencies are made and the principle of operation of the developed system is described. A comparison of the methods of transmitting control signals and the performance of different types of lamps was made as well as an assessment of the battery discharge process. The different attachment types of solar panels to their supports were highlighted, the illumination received on a public space according to the installation height of the luminaire and the used LED power as well as the requirements in terms of illumination and brightness depending on the place to be lit were discussed. The system developed consists of two solar panels, connected in parallel, one battery and six LED lamps with adjustable power. At present, the problem of modernizing the lighting of public places and roads of regional and local significance in Gitega city remains relevant. With the aim of promoting clean energy and reducing energy consumption due to global concern about climate change, the use of modern, cost-effective lighting systems based on the use of LED technology and is one of the most dynamic trends in the world at present and in the near future for the well-being of the population.
\end{abstract}

\section{Introduction}

Light is a fundamental element for human activity, the day is lit by the sun but when night comes artificial light becomes mandatory. Since solar energy is available all over the globe, the city of Gitega, now the political capital of the Republic of Burundi, located in the center of the country, is privileged to have a strong solar deposit. This work is an extended version of the report [1] presented in 2020 IEEE Conference of Russian Young Researchers in Electrical and Electronic Engineering (EIConRus), where a public Lighting by Mini Solar Power Plants in the Republic of BURUNDI is proposed. With a duration of insolation exceeding 3000 hours per year and a considerable annual average daily irradiation, this region can be a pole of excellence for the use and promotion of photovoltaic solar energy $[1,2]$. In this work, we propose a design and dimensioning of autonomous systems for street lighting using solar photovoltaic energy as the primary

*Corresponding Author: Ntawuhorakomeye Noel, noentaw1@mail.ru source. Obtaining information about the intensity of solar radiation in a specific geographic and climatic zone gives an idea of the possibility of using solar energy to generate a certain amount of electricity. The climatic conditions of the city of Gitega make this value almost constant throughout the year [2]. This is an important parameter when calculating any type of solar power plant (SPP). However, in order to improve the energy efficiency of photovoltaic lighting systems, it is necessary to use both high-efficiency photovoltaic modules as well as efficient batteries and charge regulators for energy storage and management; but also it is essential to use luminaires with high energetic efficiency (number of lumens/Watt) [3-7].

Nowadays, artificial lighting has become more than a means of obtaining light; it is an indispensable element of human life in general and in urban areas in particular [8]. The lighting of public places, traffic lanes, monuments and sites in cities and the countryside has now become a major concern for electricity 
distributors and administrative and political authorities. Public lighting plays a very important role in various places of attendance both economically and socially $[8,9]$. It is above all a measure aimed at increasing the safety of public spaces, whether in traffic areas or in relaxation and recreation areas. The objective is not to provide light only for safety purposes, but also to create a pleasant nighttime atmosphere giving a new vision and approach to the spaces [9]. To produce light, there are three main techniques [1, 8]: incandescent (classical and halogen), fluorescence and LED (Light-emitting diode). Due to the high efficiency and the absence of infrared radiation, LED lamps practically do not heat up during operation. Currently existing LED lamps consist of dozens, and sometimes hundreds of LEDs. The quality of colored light is still an unrivaled achievement of LED technology. The main difference between LED luminaires (lamps) and all others is their unprecedented long service life (up to 100,000 hours) [5, 8]. For electric lighting systems that operate at night, the period of electricity accumulation during daylight hours is a very important. A 120 amp-hours (120 Ah) accumulator battery with two 200watt solar panels $(200 \mathrm{~W})$ were used in the design of this mini SPP to power the six public lighting LEDs. The developed intelligent system is a solution for remote control of street lighting, which has the ability to control the lamps and the lighting level of each street lamp. Increasing the reliability of street lighting networks will ensure energy saving, uninterrupted power supply, and as a result, ensure road safety as the number of accidents and illegal actions is significantly reduced when the city is well lit. The use of an intelligent street lighting control system will ensure safer traffic conditions, pedestrian safety, and significantly improve the city's architectural, tourist, and commercial aspects $[10,11]$. All this with the aim of promoting clean energy, and reducing energy consumption due to global concern on climate change.

\section{Characteristics and Features of Gitega City Climate}

Gitega city is located in the center of the country about $100 \mathrm{~km}$ east of the economic capital Bujumbura. Its geographical coordinates are $3^{\circ} 25^{\prime}$ South, $29^{\circ} 55^{\prime}$ East according to Meteonorm 7.3 , Sat $=100 \%$ of PVSYST. It is part of Africa in the southern hemisphere. This region is characterized by hills composed of metamorphic rocks such as schists, quartzites and phyllites. The Gitega province is located in the Central Plateau area with an altitude ranging from 1600 to $2000 \mathrm{~m}$. It has a tropical climate tempered by altitude. Under normal conditions, the climate of the Gitega city is characterized by two (2) well-marked seasons namely the dry season, which begins in May and continues until October with minimas in June and July as well as the rainy season. The average precipitation is $1200 \mathrm{~mm}$ and the average temperature over the year $22.6^{\circ} \mathrm{C}$ (As shown in Table 1). The main nearby river is the Ruvubu with two main tributaries namely the Ruvyironza and the Mubarazi. Several districts make up the town of Gitega for about $10 \mathrm{~km}$, along and around the RN2 (national road № 2) that crosses it: Magarama, Nyamugari (Swahili district), the commercial district, the administrative district, Musinzira, Shantanya, Rutonde, Nyabiharage, Nyabututsi and Mushasha (religious district). Located on an important relief, there is significant solar irradiation whose average value received annually is estimated at $1800 \mathrm{kWh} / \mathrm{m}^{2} /$ year. The following Table shows the average temperatures, solar radiation and wind velocity, by months according to Meteonorm 7.3 , Sat $=100 \%$ of PVSYST

Table 1: Temperature, Average irradiation, Wind velocity and Relative humidity at Gitega

\begin{tabular}{|l|c|c|c|c|}
\hline & $\begin{array}{l}\text { Average } \\
\text { temperat } \\
\text { ure }\left({ }^{0} \mathrm{C}\right)\end{array}$ & $\begin{array}{l}\text { Average } \\
\text { irradiation } \\
\left(\mathrm{kWh} / \mathrm{m}^{2} /\right. \\
\mathrm{mth})\end{array}$ & $\begin{array}{l}\text { Wind } \\
\text { velocit } \\
\mathrm{y}(\mathrm{m} / \mathrm{s})\end{array}$ & $\begin{array}{l}\text { Relative } \\
\text { humidity } \\
(\%)\end{array}$ \\
\hline January & 23.3 & 149.5 & 3.30 & 64.0 \\
\hline February & 24.3 & 134.3 & 3.49 & 57.5 \\
\hline March & 24.4 & 156.9 & 3.50 & 61.1 \\
\hline April & 23.2 & 147.6 & 3.39 & 68.6 \\
\hline May & 22.7 & 151 & 3.70 & 66.5 \\
\hline June & 21.3 & 151.1 & 3.80 & 65.7 \\
\hline July & 20.7 & 158.5 & 3.80 & 64.9 \\
\hline August & 21.0 & 156.2 & 3.80 & 63.6 \\
\hline September & 21.6 & 149.7 & 3.99 & 62.5 \\
\hline October & 22.8 & 154 & 3.80 & 62.0 \\
\hline November & 22.7 & 136.0 & 3.10 & 68.3 \\
\hline December & 23.4 & 146.5 & 3.19 & 65.8 \\
\hline Year & $\mathbf{2 2 . 6}$ & $\mathbf{1 7 9 1 . 3}$ & $\mathbf{3 . 6}$ & $\mathbf{6 4 . 2}$ \\
\hline
\end{tabular}

Based on the abovementioned and presented data in the table, we can conclude that the climatic conditions of the city of Gitega are ideal for the effective use of electricity from solar panels (SP). The Figure1 shows the temperature and irradiation variation according to the months of the year.

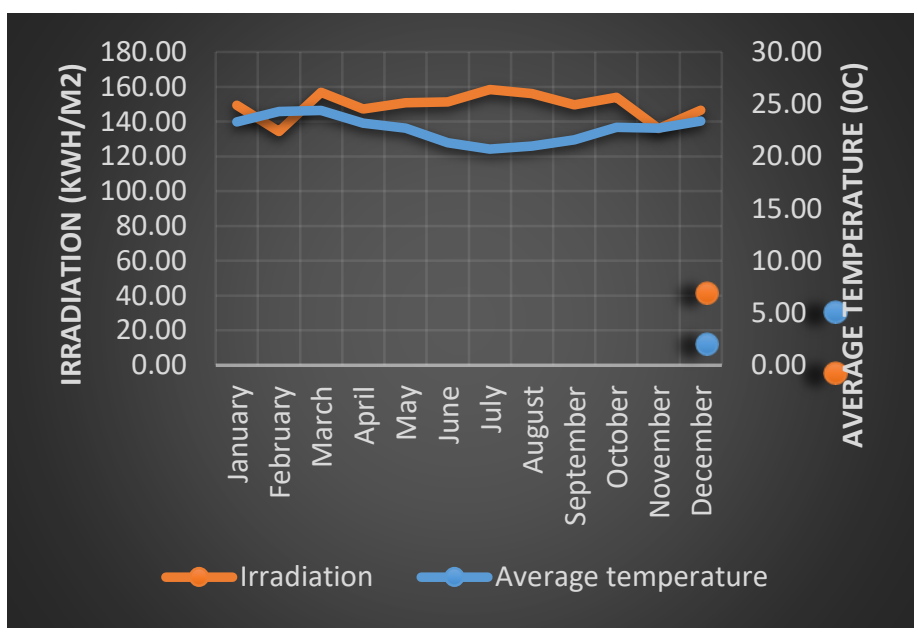

Figure 1: Temperature and Irradiation variation

Figure 2 Shows the Sun Path and Horizon Line respectively at Gitega. It is noted that the city of Gitega sees 9 hours of sunshine per day. Large solar irradiation begins to be observed at 10 o'clock, and begins to decrease at 15 o'clock with a maximum at 12 o'clock [1].

Knowing that there is no public lighting in general in this city and that the only light that the streets and public squares receive comes from the exterior lights of the surrounding houses and buildings, the development of a public lighting system is very important for the well-being of residents and passers-by, especially at night. 

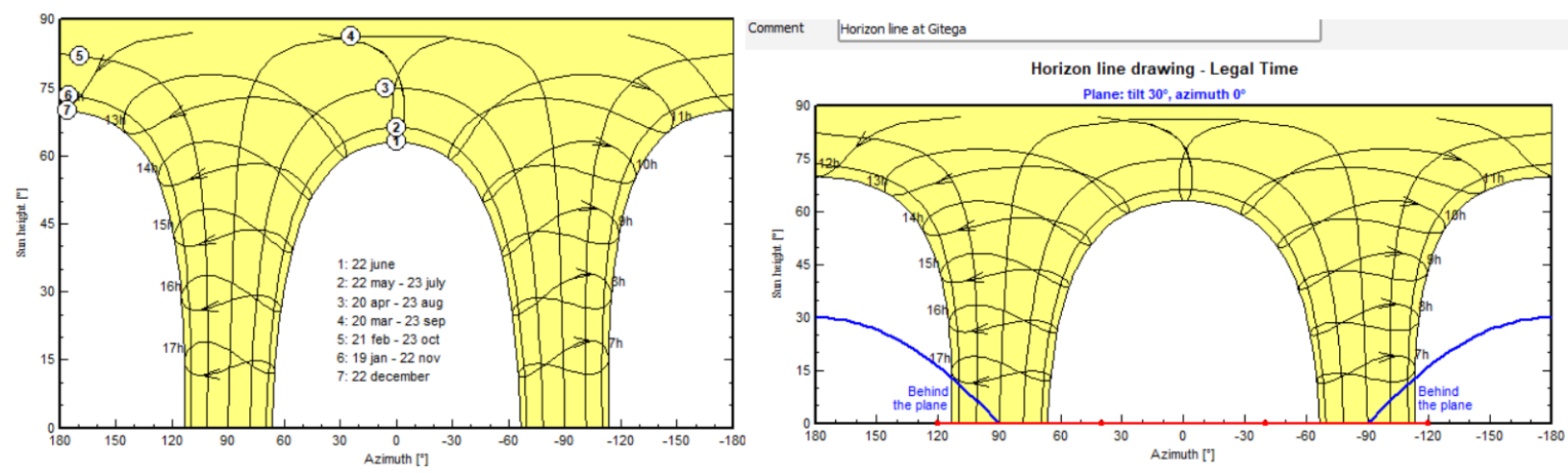

Figure 2: Sun Path Shape Horizon Line

Table 2: Requirements for Roads and Streets Lighting

\begin{tabular}{|c|c|c|c|c|}
\hline $\begin{array}{l}\text { Lighting } \\
\text { Category }\end{array}$ & Streets and Roads & $\begin{array}{l}\text { The Highest Traffic Intensity in } \\
\text { Both Directions, units / h }\end{array}$ & $\begin{array}{l}\text { Coating Average } \\
\text { Brightness, } \mathrm{Cd} / \mathrm{m}^{2}\end{array}$ & $\begin{array}{l}\text { Coating Average } \\
\text { Horizontal Illumination, lx }\end{array}$ \\
\hline \multirow[t]{3}{*}{ A } & \multirow{3}{*}{$\begin{array}{l}\text { Main roads, main } \\
\text { streets of citywide } \\
\text { significance }\end{array}$} & More than 3000 & 1,6 & 20 \\
\hline & & 1000 to 3000 & 1,2 & 20 \\
\hline & & 500 to 1000 & 0,8 & 15 \\
\hline \multirow[t]{4}{*}{ B } & \multirow{4}{*}{$\begin{array}{l}\text { Main streets of district } \\
\text { significance }\end{array}$} & More than 2000 & 1,0 & 15 \\
\hline & & 1000 to 2000 & 0,8 & 15 \\
\hline & & 500 to 1000 & 0,6 & 10 \\
\hline & & Less than 500 & 0,4 & 10 \\
\hline \multirow[t]{3}{*}{$\mathrm{C}$} & \multirow[t]{3}{*}{ Local streets and roads } & 500 and more & 0,4 & 6 \\
\hline & & Less than 500 & 0,3 & 4 \\
\hline & & Single cars & 0,2 & 4 \\
\hline
\end{tabular}

Table 3: Horizontal Illumination of Some Places

\begin{tabular}{|l|c|}
\hline Places to light & Average horizontal illumination, Lx \\
\hline $\begin{array}{l}\text { Main pedestrian streets, impassable parts of squares of categories A and B, and pre- } \\
\text { factory squares }\end{array}$ & 10 \\
\hline $\begin{array}{l}\text { Pedestrian streets: } \\
\text {-within community centers } \\
\text {-in other territories }\end{array}$ & 6 \\
\hline Sidewalks separated from the roadway on streets & $2-4$ \\
\cline { 2 - 2 } & \multicolumn{2}{|c|}{10} \\
\hline Public transport boarding areas on all categories of streets & 10 \\
\hline $\begin{array}{l}\text { Pedestrian bridges, Children's playgrounds where outdoor games equipment is } \\
\text { located }\end{array}$ & 100 \\
\hline $\begin{array}{l}\text { Pedestrian tunnel: } \\
\text {-in the daytime } \\
\text { - evening and night }\end{array}$ & 50 \\
\hline Pedestrian tunnel stairs in the evening and at night & 20 \\
\hline Household sites and waste collection sites & 2 \\
\hline
\end{tabular}

\section{Main Requirements for Public Lighting Systems}

When developing solar street lighting, it is possible to achieve maximum efficiency of the system only using, so-called "smart" technical means, which would not only control operation modes, but also control the operation of the entire system in automatic mode. Additional maintenance of street lighting should be carried out in case of violation of the recommended lighting standards (lamps fail, stop shining or Shine dimly). The working hours of 
lamps are regulated by municipal services, which approve the schedule for switching on and off lighting.

In cities and rural settlements, the requirements for lighting streets and roads vary significantly. Table 2 shows the standards for artificial lighting of roads and streets in cities and rural settlements. At the same time, the average brightness of a highway's coverage is $1.6 \mathrm{~cd} / \mathrm{m}^{2}$ in cities and at least $1.0 \mathrm{Cd} / \mathrm{m}^{2}$ outside of cities at the main entrances to airports, river and sea ports, regardless of traffic intensity [8, 12].

The average horizontal illumination at the level of coverage of impassable parts of streets, roads and squares, boulevards and squares, pedestrian streets and territories of micro districts in urban settlements should be taken according to table 3 .

At night, lighting level of city streets, roads and squares can be reduced to a standardized average brightness of more than 0.4 $\mathrm{cd} / \mathrm{m}^{2}$ or an average illumination of more than 4 lux by switching on no more than half of the lamps. It is allowed to reduce the lighting level with the regulator in order to obtain additional energy savings in the evening and morning hours of the day $[3,6]$ : by $30 \%$ with a decrease in traffic intensity to $1 / 3$ of the maximum value; and by $50 \%$ with a decrease in traffic intensity to $1 / 5$ of the maximum value.

On streets and roads at standardized values of an average brightness of $0.3 \mathrm{~cd} / \mathrm{m}^{2}$ or an average illumination of 4 lux or less, on pedestrian bridges, parking lots, pedestrian walkways and roads, internal, service and fire-fighting passages, as well as on rural streets and roads settlements, partial or complete switching off of lighting at night is not allowed. The following Table (Table
4) shows the variation of the illumination received (lux) on a public space according to the luminaire installation height and the power of the used Led (W) [13].

\section{Automatic Control Systems of Public Lighting}

Switching street lights on and off as needed is an excellent measure to save energy consumption. However, the various systems are not equally suited to this rapidly evolving technology. It is particularly interesting for public spaces used infrequently, such as public toilets, public waste collection points, and rural roads with little traffic. For areas with high safety sensitivity, it is not recommended (e.g. for busy roads, areas of heavy road or pedestrian traffic, and areas requiring overnight surveillance). On the other hand, for autonomous solar lighting systems, a regular and homogeneous consumption cycle is ideal. Uneven battery discharge due to erratic interruptions leads to rapid degradation and the need to replace them before the end of their normal lifespan. Therefore, measures to interrupt the nighttime lighting duration of such systems are only suitable to a limited extent. For solar systems, regular long-term interruptions are feasible to be managed through programmable astronomical clocks. Motion detectors are only recommended for small isolated spotlights. Automatic street lighting control systems usually operate under the control of a zone controller or server. Depending on the control algorithm, the controller generates a signal, for example, turning on a group of streetlights $[10,13,14]$. To transmit this signal to actuators, the following means are used: -low-current signal lines (twisted pair, RS-485, Ethernet, etc.); -radio channel; -GSMchannel; -signal transmission via power cable.

Table 4: Examples of illumination data for a lighting unit

\begin{tabular}{|c|l|c|c|c|c|c|c|}
\hline \multirow{2}{*}{$\begin{array}{l}\text { Installation } \\
\text { height of the } \\
\text { luminaire }\end{array}$} & Illuminated & \multicolumn{5}{|c|}{ Maximum illumination (lux) received on a road } \\
\cline { 3 - 8 } & & LED 18 W & LED 30 W & LED 50 W & LED 65 W & LED 80 W & LED 120 W \\
\hline $6 \mathrm{~m}$ & $8 \times 20 \mathrm{~m}$ & $10 \mathrm{Lux}$ & $19 \mathrm{Lux}$ & $30 \mathrm{Lux}$ & $39 \mathrm{Lux}$ & $49 \mathrm{Lux}$ & $59 \mathrm{Lux}$ \\
\hline $8 \mathrm{~m}$ & $10 \times 25 \mathrm{~m}$ & $6 \mathrm{Lux}$ & $12 \mathrm{Lux}$ & $18 \mathrm{Lux}$ & $23 \mathrm{Lux}$ & $29 \mathrm{Lux}$ & $35 \mathrm{Lux}$ \\
\hline $10 \mathrm{~m}$ & $13 \times 30 \mathrm{~m}$ & $4 \mathrm{Lux}$ & $8 \mathrm{Lux}$ & $12 \mathrm{Lux}$ & $15 \mathrm{Lux}$ & $19 \mathrm{Lux}$ & $24 \mathrm{Lux}$ \\
\hline $12 \mathrm{~m}$ & $16 \times 35 \mathrm{~m}$ & $2 \mathrm{Lux}$ & $5 \mathrm{Lux}$ & $8 \mathrm{Lux}$ & $11 \mathrm{Lux}$ & $14 \mathrm{Lux}$ & $17 \mathrm{Lux}$ \\
\hline
\end{tabular}

Table 5: Comparison of control signal transmission methods

\begin{tabular}{|c|c|c|c|c|}
\hline & 1. Low Current Control & 2. GSM-Channel & $\begin{array}{l}\text { 3. Power Transmission } \\
\text { Lines }\end{array}$ & 4.Radio Channel \\
\hline $\begin{array}{l}\text { Addressing } \\
\text { (Economically } \\
\text { Feasible) }\end{array}$ & $\begin{array}{l}\text { possible Individual lamp } \\
\text { controls }\end{array}$ & Group control only & Group control only & Group control only \\
\hline Control Method & $\begin{array}{l}\text { Digital control Protocol } \\
\text { for example based on a } \\
\text { calendar schedule }\end{array}$ & $\begin{array}{l}\text { Phone call or SMS to } \\
\text { the controller in the } \\
\text { control Cabinet }\end{array}$ & $\begin{array}{l}\text { Control via a power cable } \\
\text { connected to the controller in } \\
\text { the control Cabinet }\end{array}$ & $\begin{array}{l}\text { Radio signal transmission } \\
\text { from the control room to the } \\
\text { receiver in the control } \\
\text { cabinet }\end{array}$ \\
\hline $\begin{array}{l}\text { Factors Affecting the } \\
\text { Reliability }\end{array}$ & $\begin{array}{l}\text { Accumulation of timing } \\
\text { error }\end{array}$ & $\begin{array}{l}\text { Dependence on the } \\
\text { workload of the public } \\
\text { network of the GSM } \\
\text { operator. }\end{array}$ & $\begin{array}{l}\text { Upon failure of the required } \\
\text { manual switching cable. }\end{array}$ & $\begin{array}{l}\text { Radio interference may } \\
\text { cause the control signal to } \\
\text { be unable to be received }\end{array}$ \\
\hline Labor Costs & High labor costs & $\begin{array}{l}\text { Low labor costs through } \\
\text { public use network }\end{array}$ & $\begin{array}{l}\text { With individual lamp control, } \\
\text { cable laying is labor-intensive }\end{array}$ & $\begin{array}{l}\text { High labor costs when } \\
\text { installing transceivers }\end{array}$ \\
\hline
\end{tabular}


N. Noel et al. / Advances in Science, Technology and Engineering Systems Journal Vol. 5, No. 6, 1356-1365 (2020)

\begin{tabular}{|l|l|l|l|l|}
\hline Territory Coverage & Snap to city / region & Cellular coverage area & $\begin{array}{l}\text { The length of the control } \\
\text { power cable cannot exceed 1 } \\
\mathrm{km}\end{array}$ & $\begin{array}{l}\text { Control is possible only in } \\
\text { the area of confident } \\
\text { reception of the radio } \\
\text { signal. }\end{array}$ \\
\hline Territory Size & $\begin{array}{l}\text { City district, small } \\
\text { settlement }\end{array}$ & City and nearest suburb & Limited territory & $\begin{array}{l}\text { City and suburbs, area } \\
\text { along the motorways }\end{array}$ \\
\hline Cost Factors & $\begin{array}{l}\text { Individual control unit in } \\
\text { each lamp }\end{array}$ & $\begin{array}{l}\text { Subscription and } \\
\text { connection fees, } \\
\text { messaging }\end{array}$ & $\begin{array}{l}\text { The cost of individual power } \\
\text { cables installation }\end{array}$ & $\begin{array}{l}\text { Cost of dispatcher's } \\
\text { equipment, relay stations } \\
\text { and receivers }\end{array}$ \\
\hline $\begin{array}{l}\text { Factors Affecting } \\
\text { Maintenance Cost }\end{array}$ & $\begin{array}{l}\text { Timer adjustment is } \\
\text { constantly needed }\end{array}$ & $\begin{array}{l}\text { High repair costs for electrical } \\
\text { equipment }\end{array}$ & $\begin{array}{l}\text { A qualified dispatcher is } \\
\text { required }\end{array}$ \\
\hline
\end{tabular}

Setting up the public lighting network is easier with a computerized centralized management system. Among other functions, this system normally allows: a) Easy and quick resetting of the whole or parts of the network, for example during extraordinary events, which require a temporary adaptation of the lighting duration in a commune area. b) Accurate detection of faults and malfunctions in light points and electrical cabinets. c) Monitoring of energy consumption by the lighting network. d) Linking of network operation with climatic conditions and traffic volume. e) Management of equipment and human resources related to network maintenance.

Such a system consists of having controllers integrated into the electrical cabinets with a link to the light points or individual controllers integrated into the light points themselves. The controllers communicate with the remote management station (a computer, a tablet or a smartphone) via a wireless network, for example WIFI or radio. Note that for the control of the lighting time of streetlights, programmable time switches preferably of the so-called astronomical, digital or mechanical clock kind which are normally integrated in the control boxes as well as twilight detectors with a photoelectric cell (sensor) which are either integrated in the equipment (for example a regulator), or they are stand-alone units. Lighting controlled by a twilight switch automatically activates the switching off and switching on of public lighting according to daylight. To ensure the reliability and accuracy of the switch, it is essential to correctly position and orient the sensor so that it is not affected by random light sources or disturbed by shadows. It should also be checked and cleaned regularly to prevent dust accumulation. Twilight switches can be associated with clocks in order to cut off the control during part of the nighttime. The programmable time switches control the switching off and switching on of public lighting at specific times. They are installed in public lighting cabinets. If it is not an astronomical clock, it must be adjusted and updated regularly in order to approximate sunrise and sunset times $[8,10]$.

\section{Design Features of the Developed System and its Operation Principle}

The functional scheme of the solar-powered street lighting system developed is shown in Figure 3. It is an economical lighting system with intelligent control operating with an intelligent lamp having a step change of the luminous flux.

1. Solar panel; 2. Block of Sensor; 3. Lamp with Progressive Adjustment of the Luminous Flux; 4. Control Block; 5. Storage Battery; 6. Diagnostic Connector.
The photovoltaic solar panel (1) generates an electric current passing through the control block 4 , which includes the charge controller of the storage battery. A "smart lamp" (3) is a lamp with stepwise adjustment of the light output power. Depending on its capacity, a battery to be charged by the solar panel ensures the operation of the entire system without recharging for a period corresponding to the duration of the night. The Block (2) consisting of temperature and light sensors sends accurate temperature and illumination data to the Control Unit 4, thereby controlling the operation mode of the lamp. The light sensors in block 2 will turn on the lamp at nightfall, and turn it off as soon as the first rays of the sun appear. Lamp operates in three different modes namely: maximum power mode, average power and economy mode depending on the time of year, the solar radiation intensity and the battery charge level. In addition, if the system notices a long lamp operation in Economy mode, it evaluates the battery charge level and can switch to timer mode in which the lamp turns on in Economy mode for a time T1, after which it turns off and turns on during time T2 before sunrise. Depending on the battery charge level, the $\mathrm{T} 1$ and $\mathrm{T} 2$ times may vary in the direction of decrease or increase. A computer is connected to the public lighting system via a serial interface according to the USB 2.0 standard from the diagnostic connector 6 to allow the use of software specially designed to control all the parameters of the system, program its operation, determine the dirt level from the solar panel, change the operating modes etc.

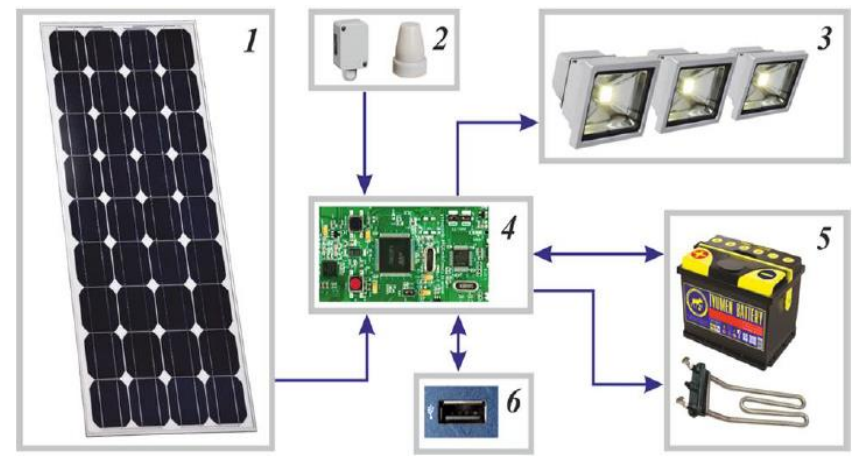

Figure 3: Block Diagram of the Developed Public Lighting

\section{Proposed System Description and Operation}

The developed street lighting system consists of smart lampslamp with a three-stage adjustment of the luminous flux: $10 \mathrm{~W}$ $20 \mathrm{~W}-30 \mathrm{~W}$ (the maximum power of each lamp is 30 watts). Each mini-SPP uses two solar panels of $120 \mathrm{~W}$ each to power six (6) smart lamps mounted 2 by 2 on three metal poles (As shown in Figure 4). The minimum total power of these lamps will be $\mathrm{P}_{\min }=$ 


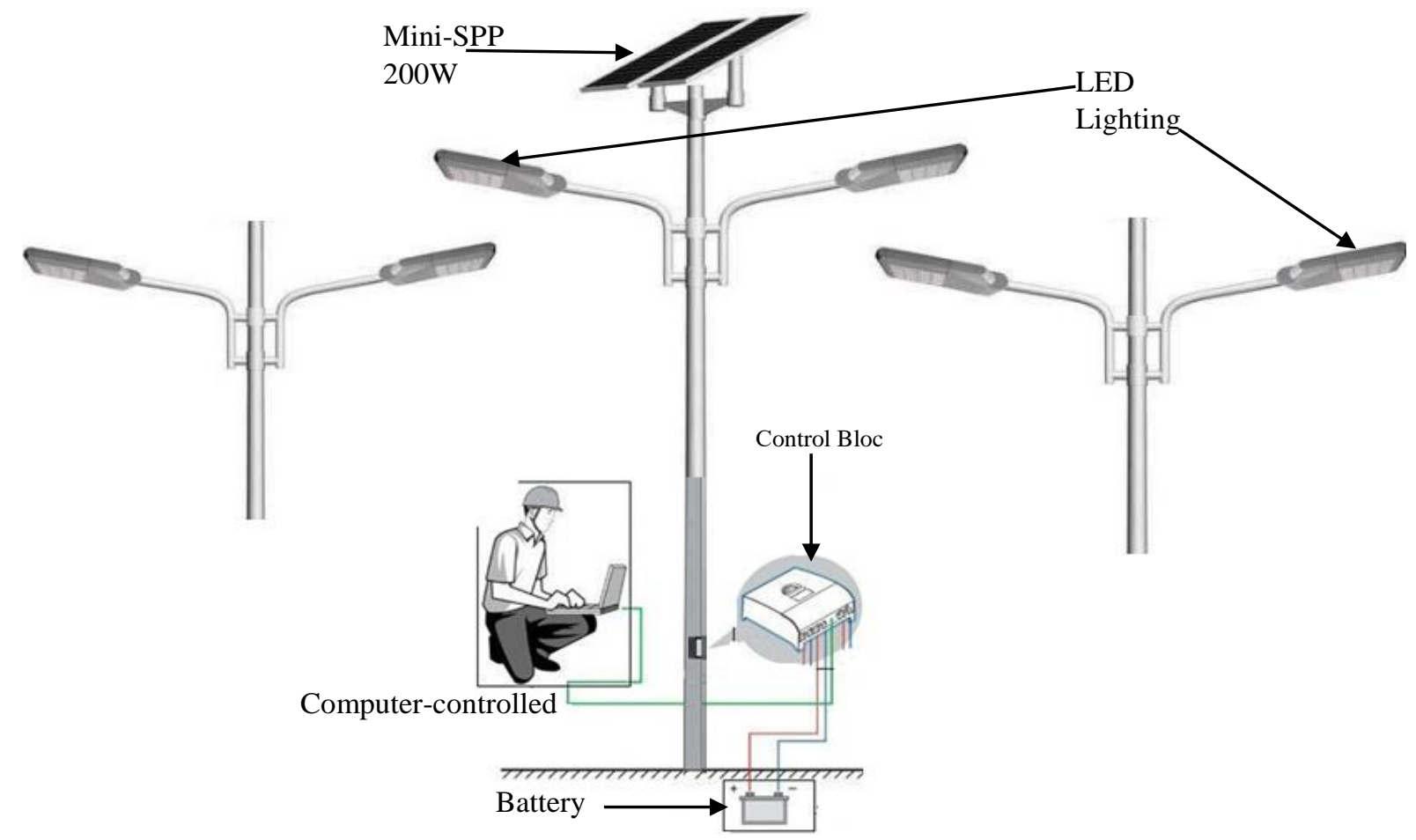

Figure 4: Developed Solar Mini-Power Plant 200 W
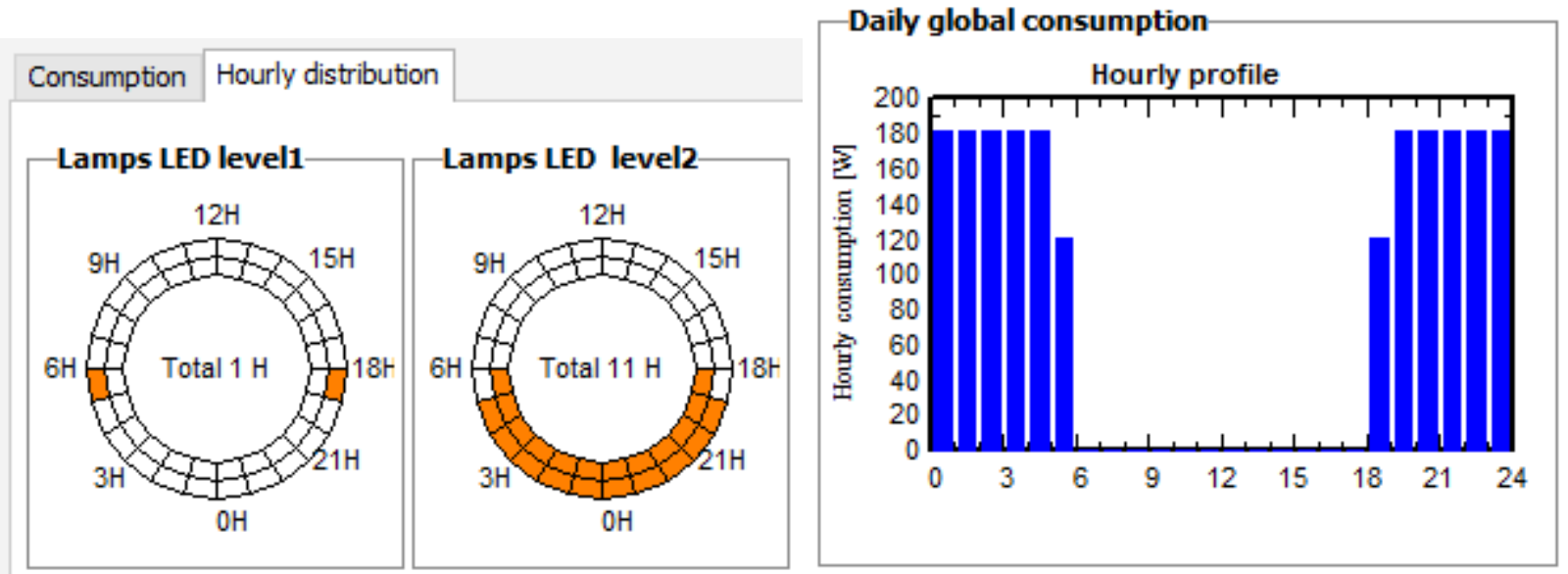

Figure 5: Lighting System hourly Distribution and Daily Consumption

$60 \mathrm{~W}$, with a maximum of $\mathrm{P}_{\max }=180 \mathrm{~W}$. As Shown in the Figure 4 , two of the lamps are installed on the central pole supporting the solar panels, the other 4 on the other 2 poles surrounding the first. A voltage of $24 \mathrm{~V}$ is transmitted from the battery of the mini solar power plant to the lamps via an underground power line. It should be noted that LED lamps are more advantageous than luminescence or incandescent lamps used in lighting systems in general. The following Table shows the relationship between the power of some lamps (W) and their luminous flux (lumen) [12].

The street lighting system shown in Figure 4 is designed to illuminate boulevards, public areas, etc. The distance between the supports on which the lamps are installed will be about $50 \mathrm{~m}$. In order to reduce the cost of design and installation of the developed system, modernized conventional LED spotlights with systematic adjustment of the luminous flux are used. The following Diagram
(As Shown in the Figure 5) shows the use state of this lighting over 24 hours (one day).

The diagram of operation and energy consumption of these lighting lamps shows that from 18: 00 (assumed time of the beginning of the night time ), the lamps illuminate under a minimum power of $10 \mathrm{~W}$ for 30 minutes after which they illuminate at their maximum power of $30 \mathrm{~W}$ each.This minimum power which lasts 30 minutes will also be observed in the morning at the end of the night time so at $05 \mathrm{~h} 30$ minutes.

\section{Solar Panels Orientation and Positioning}

In this street lighting system, the electrical energy source is usually located on the same support on which the luminaire is fixed. In this regard, special attention should be paid to the design of attachment of the solar panel to the support, since the amount 
of electricity generated will also depend on its orientation. Most often, solar panels are installed at a certain angle (declination) to the sun, in the direction of azimuth to the South or South-East (As Shown in Figure 6) [12, 15].

Table 6: Power Ratio of Various Lamps Types

\begin{tabular}{|c|c|c|c|}
\hline $\begin{array}{l}\text { Incandescent } \\
\text { lamp, W }\end{array}$ & $\begin{array}{l}\text { Fluorescent } \\
\text { lamp, W }\end{array}$ & $\begin{array}{l}\text { LED } \\
\text { lamp, W }\end{array}$ & $\begin{array}{l}\text { Luminous } \\
\text { flux, Lm }\end{array}$ \\
\hline 60 & $15-16$ & $8-10$ & 700 \\
\hline 75 & $18-20$ & $10-12$ & 1200 \\
\hline 100 & $25-30$ & $12-15$ & 1200 \\
\hline 150 & $40-50$ & $18-20$ & 1800 \\
\hline 200 & $60-80$ & $25-30$ & 2500 \\
\hline
\end{tabular}

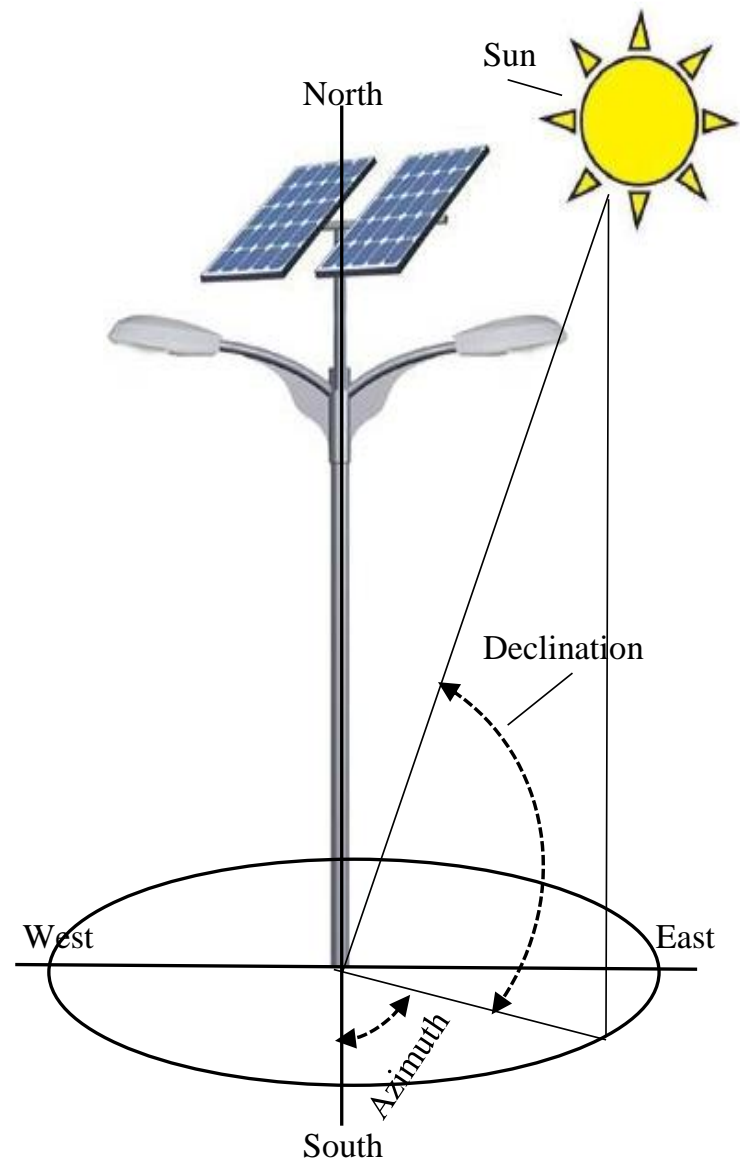

Figure 6: Solar Panel Orientation in Space

It is known that solar panels generate electricity in the absence of direct solar radiation, in cloudy weather, when the sunlight is weak and diffused, the photovoltaic system will produce electricity. The influence of various conditions on the production of solar panels as a percentage of the rated power is shown in Table 7 [12].
The tilt angle of solar panels relative to the earth's surface depends on geographical coordinates. Moreover, to increase the performance of the system, this angle must be changed during the year. As shown in Figure 7, for a fixed orientation throughout the year, the optimal tilt angle for the city of Gitega is 30 degrees.

Table 7: Dependence of Solar Panel Power on Different Conditions

\begin{tabular}{|l|c|}
\hline Conditions & $\begin{array}{l}\text { Percentage of the Maximum } \\
\text { Radiation (\%) }\end{array}$ \\
\hline Bright sun & 100 \\
\hline Light cloudy & $60-80$ \\
\hline Window glass, one layer & 91 \\
\hline Overcast weather & $20-30$ \\
\hline Artificial light indoors & $0,2-1,5$ \\
\hline
\end{tabular}

Tilt $30^{\circ}$

Azimuth $0^{\circ}$
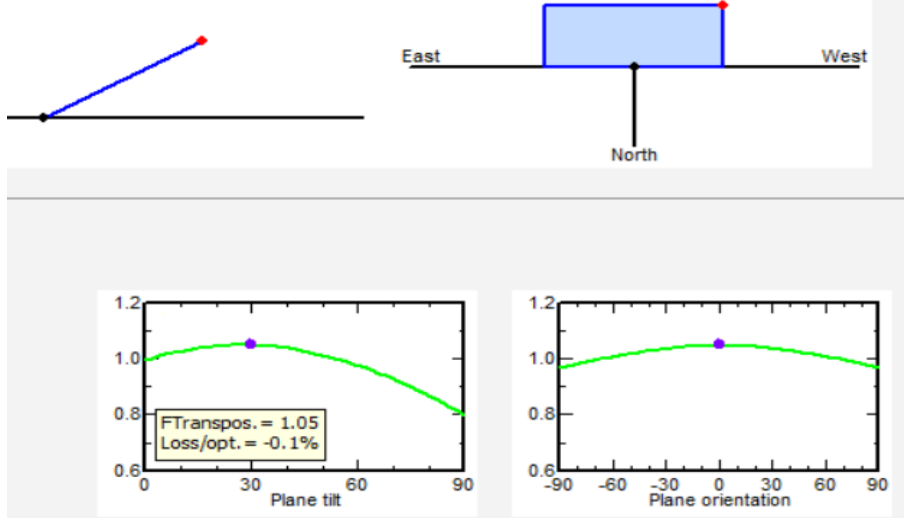

Figure 7: Tilt angle and Azimuth at Gitega

The tilt angle of a solar panel plays an important role, however small changes in the range of 0 to 5 degrees cannot have a serious effect on the system performance. Therefore, the tilt angle for localities (communes) of this region such as Bugendana, Bukirasazi, Buraza, Giheta, Gishubi, Itaba, Makebuko, Mutaho, Nyanrusange and Ryansoro will also be the same.

\section{Solar Panels Fixings to Their Supports}

Ideally, the luminaire support is fixed to a concrete footing through a metal plate to facilitate its replacement, if necessary. Depending on the function, the aesthetic appearance, the space and the environment, several types of supports can be identified, for example, poles made of steel, aluminum, cast iron, concrete, wooden etc. [12].

At present, metal supports are the most often used. Their manufacturing is more technologically advanced; they have a relatively small mass and retain their operating characteristics for a sufficiently long time. As the metal support is hollow inside, it is possible to run cables through it, connecting the solar panel to the control block and to the storage battery. In general, four (4) fixing points are used to fix a solar panel on a metal support. It is also taken into account that the panel should be oriented vertically, not horizontally. Table 8 shows some standard methods of solar panels fixing. 
Table 8: Solar Panels Fixing

\begin{tabular}{|c|c|c|c|}
\hline Denomination & $\begin{array}{l}\text { Solar Module } \\
\text { Width }\end{array}$ & Landing Dimensions & Image \\
\hline $\begin{array}{l}\text { MSU51585 Universal fastening } \\
\text { of the solar module } 50-150 \mathrm{~W} \text { to } \\
\text { the pipe up to } 85 \mathrm{~mm}\end{array}$ & up to $700 \mathrm{~mm}$ & $\begin{array}{c}\text { Pipe } \varnothing 45-85 \mathrm{~mm} \text { or on } \\
\text { the wall }\end{array}$ & \\
\hline $\begin{array}{l}\text { MSU515220 Universal } \\
\text { fastening of solar modules } \\
50150 \mathrm{~W} \text { to the pipe up to } \\
220 \mathrm{~mm}\end{array}$ & up to $700 \mathrm{~mm}$ & Pipe $\varnothing 80-220 \mathrm{~mm}$ & \\
\hline $\begin{array}{l}\text { MSU153085 Universal } \\
\text { fastening of solar modules } 150 \text { - } \\
300 \mathrm{~W} \text { on a pipe up to } 85 \mathrm{~mm}\end{array}$ & up to $1000 \mathrm{~mm}$ & $\begin{array}{c}\text { Pipe } \varnothing 45-85 \mathrm{~mm} \text { or on } \\
\text { the wall }\end{array}$ & \\
\hline $\begin{array}{l}\text { MSU1530240 Universal } \\
\text { fastening of the solar module } \\
150-300 \mathrm{~W} \text { on the pipe up to } \\
220 \mathrm{~mm}\end{array}$ & up to $1000 \mathrm{~mm}$ & Pipe $\varnothing 80-240 \mathrm{~mm}$ & \\
\hline $\begin{array}{l}\text { MSU2x1530280 Universal } \\
\text { fastening of two solar modules } \\
150-300 \mathrm{~W} \text { on a pipe (wall) } 50- \\
280 \mathrm{~mm}\end{array}$ & up to $1000 \mathrm{~mm}$ & $\begin{array}{c}\text { Pipe } \varnothing 50-280 \mathrm{~mm} \text { or on } \\
\text { the wall }\end{array}$ & \\
\hline
\end{tabular}

Note that it is necessary to use a design that facilitates the changeability of the tilt angle of the solar panels according to the time of day or year in order to increase the efficiency of the minisolar power plant for public lighting.

\section{Solar Panels Power Calculation}

The energy generated by a solar panel with a power Pw for a selected period is calculated as follows [16, 17]:

$$
W=\frac{k \cdot E \cdot P_{w}}{1000}
$$

E - insolation value for the selected period; $\mathrm{Pw}$ - solar panel power, $\mathrm{k}$ - coefficient equal to 0.5 and 0.7 in summer and winter periods, respectively. This factor takes into account the solar panels heating by the sun, as well as the incidence angle during the day. The insolation value $\mathrm{E}=4.91 \mathrm{kWh} / \mathrm{day}$.

The solar panel power to be used is calculated taking into account the daily consumption of all the LED lamps operating during the night hours. Remembering that they are of the adjustable power type and therefore their minimum power $P_{\text {¿lamp }}$ will be 60 watts, their maximum $180 \mathrm{~W}$. Their maximum daily energy consumption $W_{\text {cons. }}$ is given by (1) as follow:

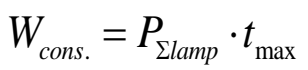

где $t_{\max }$ - the operating time of the lamps 
The latitude of the city of Gitega and the sun declination on which the average longitude of the day depends, give an interval of the day equal to 12 hours. Accordingly, the maximum daily energy consumption of the system will be $2040 \mathrm{Wh}$ /day according to (1). Since the average number of hours of sunshine is estimated at 9 hours $(9 \mathrm{~h})$ per day, to determine the daily energy production (generation) of solar panels, it is necessary to multiply their rated power $P_{n}$ by their operating time per day: $W_{g e n}=P_{n} \cdot t_{o p}$

Where $t_{o p .}$ - Operating time $(9 \mathrm{~h}), W_{g e n}$ - Daily energy generation. This daily energy produced by the solar panels will be $2016 \mathrm{Wh}$ /day. The $120 \mathrm{~W} 24 \mathrm{~V}$ solar panels that will be chosen from the ranges produced by different manufacturers must have an optimal operating current of at least 6.7 A.

\section{Battery Capacity Assessment and Calculation}

The developed public lighting systems are intended to work during the night hours, while during this time the solar panels do not generate the electric energy, the electricity stored in the batteries is used. The capacity of the battery to be used, i.e. the amount of energy it can store, plays a big role. Their total capacity depends on the number of storage batteries, and therefore the power of the solar power plant in general. Storage batteries in a solar power plant must meet a number of requirements. They must withstand a large number of charge-discharge cycles. When calculating the parameters of the storage battery, it is necessary to take into account the energy losses during its storage and transformation. Conventional car batteries do not withstand a large number of cycles and have significant self-discharge. Most often, special storage batteries are used for solar power plants. Table 9 shows the states of charge (Battery charge levels) of a 12-volt battery depending on the temperature $[12,18]$.

Table 9: 12V- Battery Charge Status Assessment

\begin{tabular}{|l|c|c|c|}
\hline \multirow{2}{*}{$\begin{array}{l}\text { Battery } \\
\text { charge } \\
\text { level, } \%\end{array}$} & \multicolumn{3}{|l|}{$\begin{array}{l}\text { Electromotive force (EMF), depending on } \\
\text { temperature }\end{array}$} \\
\cline { 2 - 4 } & $+20 \ldots+25^{\circ} \mathrm{C}$ & $+5 \ldots-5^{\circ} \mathrm{C}$ & $-10 \ldots-15^{\circ} \mathrm{C}$ \\
\hline 100 & $12,70-2,120$ & $12,80-13,00$ & $12,9-13,10$ \\
\hline 75 & $12,55-12,65$ & $12,65-12,75$ & $12,75-12,85$ \\
\hline 50 & $12,20-12,30$ & $12,30-12,40$ & $12,40-12,50$ \\
\hline 25 & $12,00-12,10$ & $12,10-12,20$ & $12,20-12,30$ \\
\hline 0 & $11,70-12,00$ & $11,80-12,00$ & $11,120-12,10$ \\
\hline
\end{tabular}

The energy generated and stored in the battery during the day is used at night to power the load (streetlights) of public lighting. This energy shows the capacity of the battery; i.e. how long it can power the load if it is fully charged. The change in battery capacity $\Delta \mathrm{C}$ during the load supply time $\Delta t_{n i g}$. is determined by the expression (2):

$$
\Delta C=\frac{P_{n}}{U_{n}} \cdot \Delta t_{\text {nig. }}=\frac{P_{n}}{U_{n}} \cdot\left(24-\Delta t_{\text {dayl. }}\right)
$$

где $\boldsymbol{P}_{n}$ - rated load power; $U_{n}$ - rated load voltage; $\Delta t_{n i g}$. the night time interval (12hours); $\Delta \mathrm{t}_{\text {dayl. }}-$ day time interval
Battery manufacturers define the final discharge voltage, once reached, the battery must be disconnected from the load and charged, this because deep discharge can damage it. A battery should not be more than 70-80\% discharged for it to work for a long time. The battery discharge level is determined by the expression [16]:

$$
S_{r}=\frac{C_{n}-C_{\min }}{C_{n}} \cdot 100 \%=\frac{\Delta C}{C_{n}} \cdot 100 \%
$$

The required capacity $C_{n}$ of the accumulator battery is obtained from (3) while taking into account (2):

$$
C_{n}=\frac{100}{S_{r}} \cdot \frac{P_{n}}{U_{n}} \cdot \Delta t_{\text {nig. }}
$$

In the city of Gitega, taking into account that the nighttime interval is 12 hours, with the 200-Watt solar panels as it was said above, a 120 Ah will be ideal for this mini solar power plant consisting of six LEDs of street lighting. Its energy capacity will be $2880 \mathrm{Wh}$. The higher the voltage supplied to the load, the lower the capacity can be, since the discharge current $I_{r}=\frac{P_{n}}{U_{n}}$ of the storage battery will be lower. For conventional lead acid batteries, the maximum discharge current is limited to a value that, in amperes, is between 5 and 25 times the battery capacities. The lower the discharge current, the lower the power loss, and therefore the higher the efficiency of the system. It is the increase in voltage and decrease in current that explains the use of voltage $24 \mathrm{~V}$ instead of $12 \mathrm{~V}$, when placing "smart lights" at a significant distance from the solar mini-power plant.

\section{Conclusions}

The task of our research was to develop and study the public lighting system of the city of Gitega using mini solar power plants as a source of renewable energy. This project was designed taking into account the current state of the lighting in Gitega, the current global trends, as well as the great importance of public lighting in general and through photovoltaic solar power plants in particular such as: increasing the citizens' safety, reducing the number of crimes and offenses and increasing their detection potential, reducing cabling costs for transmission systems, reducing the burden on emergency services and electrical technicians. This public lighting system with an automated solar power plant will regulate energy consumption, monitor the integrity of the equipment and quickly send a signal to operating personnel on emergencies on the network. The current state of public lighting in the city of Gitega and its surroundings is poor due to the lack of financial resources needed using traditional energy sources. The development of such solar street lighting systems that would not require large investment costs, promote clean energy, reduce energy consumption and which maintenance would be carried out once or twice a year, is very relevant. 


\section{Conflict of Interest}

The authors declare no conflict of interest regarding the publication of this paper.

\section{References}

[1] N. Ntawuhorakomeye, M.P. Belov, "Development and Analysis of Public Lighting by Mini Solar Power Plants in The Republic of BURUNDI," in 2020 IEEE Conference of Russian Young Researchers in Electrical and Electronic Engineering (EIConRus), IEEE, St. Petersburg, Russia: 785-790, 2020, doi:10.1109/EIConRus49466.2020.9039030.

[2] Ministry of Energy and Mines of the REPUBLIC OF BURUNDI, Opportunités dans le secteur des énergies renouvelables au Burundi Ministère de l'Energie et des Mines REPUBLIQUE DU BURUNDI, Bujumbura,Burundi, 2012.

[3] D. V. Shatilov, Проект «Программы внедрения автономных систем энергоснабжения уличного освещения на основе использования экономичных светодиодных светильников и солнечных батарей для стимулирования применения методов энергосбережения в жилищнокоммунальном хозяйстве, Svetorezerv LLC, Moscow, 2008.

[4] C. Muchunku, K. Ulsrud, D. Palit, W. Jonker-Klunne, "Diffusion of solar PV in East Africa: What can be learned from private sector delivery models?," WIREs Energy and Environment, 7(3), 2018, doi:10.1002/wene.282.

[5] I.A. Suvorov, Электротехнологические промышленные установки и освещение (2009) - книга автора Суворова И.А. | НЭБ, Kirov, 2009.

[6] R. Ciriminna, F. Meneguzzo, L. Albanese, M. Pagliaro, "Solar street lighting: a key technology en route to sustainability," Wiley Interdisciplinary Reviews: Energy and Environment, 6(2), e218, 2017, doi:10.1002/wene.218.

[7] V.K. Satyakar Veeramallu, S. Porpandiselvi, B.L. Narasimharaju, "Analysis and implementation of soft-switched bidirectional buck-boost DC-DC converter for solar PV-fed LED street lighting systems," International Journal of Circuit Theory and Applications, 47(12), 1990-2018, 2019, doi:10.1002/cta.2706.

[8] G.P. Kolesnik, Электрическое освещение Основы проектирования Учебное пособие.pdf, Vladimir, 2006.

[9] Metode penelitian Nursalam, 2016, A.. Fallis, "GUIDE TECHNIQUE MODULE 3 : ECLAIRAGE PUBLIC," Journal of Chemical Information and Modeling, 53(9), 1689-1699, 2013.

[10] N. Khatavkar, A.A. Naik, B. Kadam, "Energy efficient street light controller for smart cities," in 2017 International Conference on Microelectronic Devices, Circuits and Systems, ICMDCS 2017, Institute of Electrical and Electronics Engineers Inc.: 1-6, 2017, doi:10.1109/ICMDCS.2017.8211714.

[11] R.C. Marques, R.R. Geddes, "THE USE OF PPP ARRANGEMENTS IN STREET LIGHTING: A WIN-WIN OPTION?," in Annals of Public and Cooperative Economics, Wiley-Blackwell Publishing Ltd: 311-327, 2019, doi:10.1111/apce.12229.

[12] A.S. Stolkov, Разработка эффективной системы уличного освещения с питанием от солнечной мини - электростанции, Altai State Technical University, 2018.

[13] Р.Ф.Д.А. Медведева, Автоматизированные системы управления наружным освещением. Опыт Москвы - ЭнергоСовет.ru, 2011.

[14] M. Wadi, A. Shobole, M.R. Tur, M. Baysal, "Smart hybrid wind-solar street lighting system fuzzy based approach: Case study Istanbul-Turkey," in 2018 6th International Istanbul Smart Grids and Cities Congress and Fair (ICSG), IEEE: 71-75, 2018, doi:10.1109/SGCF.2018.8408945.

[15] E. Alsakkaf, "An Automatic Off-Grid Solar Street Lighting System," IJIREEICE, 4(3), 1-3, 2016, doi:10.17148/IJIREEICE.2016.4301.

[16] M.P.Belov. N. Ntawuhorakomeye, "TECHNICAL METHOD OF CALCULATING POWER OF SOLAR POWER PLANTS IN TROPICAL CLIMATES AS IN THE REPUBLIC OF BURUNDI,” Izvestiya SPbGETU "LETI," 8, 66-74, 2019.

[17] N. Ntawuhorakomeye, M.P. Belov, "Replacement of Liquid Fuel by Solar Electrical Installation for the Production of Electric Energy by DieselGenerators of the «REGIDESO» Industrial Group in the Republic of Burundi," in 2019 IEEE Conference of Russian Young Researchers in Electrical and Electronic Engineering (EIConRus), IEEE: 1021-1024, 2019, doi:10.1109/EIConRus.2019.8656909.

[18] M.D. Vijay, K. Shah, G. Bhuvaneswari, B. Singh, "LED based street lighting with automatic intensity control using solar PV," in 2015 IEEE IAS Joint Industrial and Commercial Power Systems / Petroleum and Chemical Industry Conference (ICPSPCIC), IEEE: 197-202, 2015, doi:10.1109/CICPS.2015.7974074. 